\title{
Saving and Investment Pattern: Assessment and Prospects
}

\author{
Deepika Dhawan*, Sushil Kumar Mehta \\ School of Business, Shri Mata Vaishno Devi University
}

$\begin{array}{ll}\text { Article history: } & \\ \text { Received: } & 16 / 04 / 2019 \\ \text { First Revision: } & 28 / 05 / 2019 \\ \text { Second Revision: } & 12 / 06 / 2019 \\ \text { Third Revision: } & 18 / 07 / 2019 \\ \text { Accepted: } & 05 / 08 / 2019 \\ \text { Published: } & 02 / 09 / 2019\end{array}$

\begin{abstract}
Relevance: This study is conducted to look into the investor rationality by examining the pattern of saving and investment in the city of Jammu situated in Jammu and Kashmir, India.

Research Objective: The objective of this study is to see the association of saving and income; reasons for saving; and preferences of investors for different investment instruments through administering the structured questionnaire.

Methodology: Respondents are conveniently selected based on judgment. One -Way ANOVA, ANCOVA, and MANOVA are used to identify and understand the patterns of saving and investment and underlying triggers for the same.

Findings: A relationship between saving and income is found, after controlling for the effects of variables, namely, age, gender, and occupation. Likewise, the impact of gender on financial literacy and awareness is found. This study also finds that people prefer safe and liquid investments with tax benefits, higher returns, and fewer lock-in-periods.

Implications: The outcome will help financial consultants and investment managers to know more about the psyche and the level of financial literacy of people, and thus to help them in their objective of garnering funds and invest at a significant level and, finally helping in the capital formation.
\end{abstract}

Keywords: Investor Rationality, Annual Savings, Investment, Annual Income, Underlying Triggers

JEL Classification: C83, D14, D31, E21, G1

\section{Introduction}

Life is inherently uncertain. As for the changes happening in all the dynamics, as to how we are living our life today, shapes our future as money spent/ saved or invested carves the path for life. Sood and Kaur (2015) propounded that life longevity, along with uncertainty about future expenses make it a necessity that we save today to ensure our freedom and sense of security. One can ascertain its importance by asking oneself: 'What if I lost my job today?' 'How am I going to pay for my dream house, expensive education for my kids, in case any unfortunate event shakes the foundation of my income and savings?' When we invest what we save for capital appreciation

\footnotetext{
* Corresponding author.

E-Mail address: 17dbu002@smvdu.ac.in

ORCID: 0000-0001-8626-0660
} 
(Young et al., 1995) and surplus income (Seward, 1952), we try to ensure our future. The concept of 'Time value of money' explains those reasons. It can be beneficial to ascertain the direction (risky vs. non-risky) and depth (the extent of our saving/investment to income) of our saving and investment patterns. After all, the old wise saying 'one bird in the hand is better than two in the bush' is still considered golden. There are different studies (Singh 2018; Panday, 2015; Jain et al., 2012) conducted in different sectors to see the saving and investment pattern of people. These studies help to understand the psyche of investors (Singh, 2006), which ultimately becomes a building block of capital formation in the country. However, in the state of Jammu \& Kashmir $(\mathrm{J} \& \mathrm{~K})$, these types of studies have been abysmal. The state has special autonomy under Article 370 of the Constitution of India (Ministry of Law and Justice, 2018) and different demography, which helps to mold the psyche of people residing here. So to highlight different approaches to saving and investment in the state of J\&K, this study is conducted to know about the relationship of annual income with saving, age with investment and the impact of gender on the investment decisions. In this exploration, we fill this examined hole through investigation in Jammu city, a territory where there has been little previous research. This study will help to create opportunities for investors and investees as people have funds but need a guiding hand for the right opportunities at the right time as is required in any successful venture.

It is imperative for an investment manager to understand the motivation behind saving and investment decisions of an individual investor that could range from cognitive to demography (Kulkarni, 2014; Das \& Jain, 2014; Sireesh \& Luxmi, 2013). This study is conducted to know the rationale behind the decisions of an investor, which can be influenced by cognitive, emotional, and herding factors (Perera, 2016). The twofold reasons for the study are:

1) To evaluate the habit of saving and patterns of investment in the city of Jammu.

2) To analyze the investment selection behavior of people in Jammu.

The remainder of the paper is organized as follows: The next segment reviews relevant literature from India and the rest of the World, which is followed by the methodology used to conduct the research. The ensuing area presents results and discussion. Next, the paper sets out a few administrative implications of the investigation, concluding the results, stating the impediments, and recommending road for future research, under the heading 'Conclusions and Recommendations.'

\section{Review of Literature}

Macro variables with micro-foundations, like saving and investment, should be instilled in people in such a way that help a country to prosper. In this, financial literacy plays a significant role (Arora, 2016). So, studies have been conducted to know about the level of financial literacy among various groups of people.

\section{Evidence from India}

This part deals with the previous studies to enlighten us about the issues, reasons, motivation, and fear factors that make up the psyche of an individual investor. In simple terms, to gain from an investment, it is necessary to know all about investment instruments and to match them with an individual's long term objectives according to the market risk. Financial literacy explains the combination of these factors (Senthil, 2015; Arora, 2016). Numerous surveys have been done in this regard, namely, the studies conducted by Singh (2006) in Bangalore and Bhuvneswar city; Samudra and Burghate (2012) in Nagpur; Bhushan (2014) in Himachal Pradesh; Das (2016) in Varanasi city; Saikia (2018) in Mumbai city; Shukla (2017) in Kanpur; Panday and Kathavarayan (2015) in Puducherry region. These studies have found the level of awareness in people about 
investment options and their inherent risks therein, whereas Chakraborty and Digal (2012) studied the behavior of individual respondents from the state of Orissa to analyze the preferences for investment options. Gupta and Agarwal (2013) have reported what constitutes part of saving and investment in urban cities.

Similarly, to see the trends of saving and investment, studies have been conducted profession wise and gender-wise. The profession of teachers has always fascinated the researchers as a financially literate teacher can raise socially responsible residents of a country. The study conducted by Jain et al. (2012) in the Udaipur district of Rajasthan, found that the majority of teachers made budgets and planned for money constraints accordingly. The rationale for saving varies from the education of their children to marriage along with their security after retirement. Achar (2012) found that individual traits like age, gender, along with marital status and lifestyle, are the determining reasons for their investment. Virani (2012) has concluded the same in the study conducted in Rajkot city, Gujarat; Parimalakanthi and Kumar (2015); Somasundaram (1999) in Coimbatore which led the researcher to believe a preference for bank deposits. Nayaki (2014) also reported a preference for negotiable instruments. Bindu (2017) has found a preference for liquid assets with risk-free returns along with tax benefits and capital appreciation, whereas Surendar and Sarma (2018) have found a satisfactory level of financial literacy irrespective of the subject they taught in the city of Warangal.

Davar and Gill (2009) have studied the behavior of respondents to know about the patterns of investment decision making in the Indian households and found that satisfaction, opinion, familiarity, and demography played a crucial role in the investment decision making.

Bahl (2012) and Arora (2016) have studied the preference of working women in Punjab and Rajasthan, respectively, regarding their investment behavior. Whereas the formerly found onethird of women are more conscious about their investment plan, the latter found that single women are more literate on the matters of financial literacy but still lack sufficient knowledge on the matter.

\section{Evidence from the rest of the World}

Research on financial literacy has gained popularity worldwide after liberalization and globalization. Various surveys conducted in different parts of the World support this fact. In the working paper for the OECD Department of Economics and Statistics, Dean et al. (1989) have tried to find the saving trend and behavior for OECD Countries and found a reduction in rates for national investment and saving for the last two decades because of slow population growth and post-war reconstruction. Ozcan et al. (2003) have found that financial market development, life expectancy, macroeconomic stability, economic crisis, and external factors may be the core policy instruments in Turkey for the saving behavior. Prinsloo (2000) has explained the determinants of saving in various sectors and concluded that private sector saving is more resilient to Gross Domestic Product (GDP) in the long run. Kgomo (2018) has found that social, cultural disposition and psychological factors affect more than risk \& return of investment. French and Poterba (1991) have stated that because of investors' choices \& not for institutional setbacks, investors prefer to invest in their home country while not diversifying their portfolio because of their belief that it is a better choice to invest in their home country, whereas Sturm (2014) has studied unobservable investor sentiments through the Turning Point Methodology in order to close the gap between technical analysis and behavioral finance. Melo and Tybout (2015) have explored, in their working paper for the World Bank, the consequence of financial liberalization on investment and saving in Uruguay and found increased leverage and average financial costs in small firms in comparison to large small firms suggesting improved credit-allocation mechanisms. Agrawal et al. (2009) have studied saving behavior in 5 developing economies, namely Sri Lanka, Bangladesh, Pakistan, India, and Nepal and found that income, foreign 
savings rate, access to banking institutions and the dependency rate determined savings. Nasir et al. (2005) have propounded that for economic development and growth, people should be more reliant on domestic saving instead of foreign sources. Adeyemo and Bamire (2005) have studied the preferences and the patterns of investment of cooperative farmers in South Nigeria and found the amount of money borrowed, income and loan repayment influenced saving patterns whereas fund borrowed impacted investment behavior. Hibbert et al. (2012) have studied the association between the management of retirement savings with the financial edification of English and finance professors in the USA and found the latter to be more active in managing their retirement savings. Olsen and Cox (2011) have tried to find the impact of gender on the awareness and reaction to investment risk and discovered that women financial specialists weigh hazard traits, for example, a probability of misfortune and uncertainty, more vigorously than their male associate.

\section{Methodology}

A descriptive design has been used for the present research. The period for the study is the $2^{\text {nd }}$ quarter of 2018-19. In this study, 184 respondents have been selected based on judgment. Each respondent has been taken as a sampling unit and asked to fill a structured questionnaire. Initially, questionnaires had been sent to 250 respondents, among whom 38 did not respond, and 28 were incomplete. The responses filled us in the saving and investment patterns of the people of Jammu city. Tables have been used to describe a series of performances of different financial instruments. IBM SPSS Statistics 23 version has been used to analyze the data. Various techniques, namely One-Way ANOVA, ANCOVA, MANOVA, and frequency distribution, have been applied.

\section{Results and Discussion}

According to the survey, out of 184 respondents included in the sample, $65 \%$ are males and $35 \%$ females. The majority of the respondents have belonged to the age group of $40-60$ years (52\%), followed by age groups $20-30$ years $(30.5 \%), 30-40$ years $(13.5 \%)$ and above 60 years $(4 \%)$. The household income of these people has ranged from less than Rs.100000 p.a. to more than Rs.500000 p.a. Savings have ranged from below $10 \%$ to more than $50 \%$, but the majority of them (43\%) saved between $10-20 \%$ of their income. Categorization, according to their occupation, has shown that $74 \%$ earn from their job, $9 \%$ from their business, and the remaining $17 \%$ from the other avenues. (Refer to Table A1). 
Table A1. Demographic Profile of Respondents (Out of 184)

\begin{tabular}{|c|c|c|c|}
\hline $\begin{array}{l}\text { Demographic } \\
\text { Variable }\end{array}$ & Particulars & Frequency & Percentage \\
\hline \multirow{2}{*}{ Gender } & Male & 120 & 65 \\
\hline & Female & 64 & 35 \\
\hline \multirow[t]{2}{*}{ Total } & & 184 & 100 \\
\hline & Below 20 & 0 & 0 \\
\hline \multirow{4}{*}{ Age (in years) } & Between 20-30 & 56 & 30.5 \\
\hline & Between30-40 & 24 & 13.5 \\
\hline & Between 40-60 & 96 & 52 \\
\hline & Above 60 & 8 & 4 \\
\hline \multirow[t]{2}{*}{ Total } & & 184 & 100 \\
\hline & Less than 100000 & 8 & 4.3 \\
\hline \multirow{3}{*}{$\begin{array}{l}\text { Annual } \\
\text { Rs.) }\end{array}$} & $100000-300000$ & 24 & 23 \\
\hline & $300000-500000$ & 32 & 17.4 \\
\hline & $500000 \&$ Above & 120 & 65.3 \\
\hline \multirow[t]{2}{*}{ Total } & & 184 & 100 \\
\hline & Below 10\% & 24 & 13 \\
\hline \multirow{3}{*}{$\begin{array}{l}\text { Annual } \\
\text { Rs.) }\end{array}$} & $10-20 \%$ & 88 & 48 \\
\hline & $20-50 \%$ & 56 & 30 \\
\hline & $50 \% \&$ Above & 16 & 9 \\
\hline \multirow[t]{2}{*}{ Total } & & 184 & 100 \\
\hline & Service & 136 & 74 \\
\hline \multirow[t]{2}{*}{ Occupation } & Business & 16 & 9 \\
\hline & Any Other & 32 & 17 \\
\hline Total & & 184 & 100 \\
\hline
\end{tabular}

They want this money for a combination of needs including the education of their children (9\%), housing $(9 \%)$ and future benefits $(22 \%)$ in the form of either capital appreciation or regular income after retirement, whereas majority (48\%) respondents want it for the combination of these items. The reason cited for either saving or investment for some $(13 \%)$, which included mainly respondents between age groups 20-30 years, is luxury vacations. (Refer to Table A2)

Table A2. The objective for either Saving or Investment

\begin{tabular}{lc}
\hline Particulars & Number of Respondents(Percentage) \\
\hline House & $16(8.7)$ \\
Education & $16(8.7)$ \\
Retirement Plans & $40(21.7)$ \\
Combination of these & $88(47.8)$ \\
Any Other Option & $24(13.0)$ \\
\hline Source: Primary Data &
\end{tabular}

The study shows that people today prefer different combinations of instruments to fulfill their needs. $52.4 \%$ of respondents prefer a combination of tax-saving, high yield \& security features in investment. $17.4 \%$ prefer tax-saving, whereas $13 \%$ prefer high yield in investment. (Refer to Table A3) 
Table A3. Factors Influencing Investment Decisions

\begin{tabular}{lc}
\hline Factors & Frequency (Percentage) \\
\hline Tax Saving & $32(17.4)$ \\
High Yield & $24(13)$ \\
Security & $8(4.3)$ \\
Combination of these & $96(52.4)$ \\
Any Other & $0(0)$ \\
Tax Saving \& Security & $8(4.3)$ \\
Tax Saving \& High Yield & $8(4.3)$ \\
High Yield \& Security & $8(4.3)$ \\
Total & $\mathbf{1 8 4}(\mathbf{1 0 0 )}$ \\
\hline Source: Primary Data
\end{tabular}

Source: Primary Data

When asked for the reasons for choices, most respondents (52\%) have preferred Fixed Deposits, followed by Savings Account (46\%) and Public Provident fund (39\%) for safety reasons. Some respondents $(17 \%)$ have responded that after these choices, they preferred any combination as a safety tool for their future. Others $(8 \%)$ wanted to invest in mutual funds either through equity or debt for fast growth. (Refer to Table A4).

Table A4. Preference for Investment Options

\begin{tabular}{lc}
\hline Particulars & Number of Respondents \\
\hline Savings Account & 24 \\
Fixed Deposits & 32 \\
PPF & 24 \\
Savings, FD \& PPF & 8 \\
FD and PPF & 24 \\
Savings, FD, PPF, and Others & 8 \\
Equity, Debt, Savings \&PPF & 8 \\
Equity, Debt, RD \& FD & 8 \\
Savings, RD \& FD & 16 \\
Any Combination & 32 \\
Total & $\mathbf{1 8 4}$ \\
Source: Primary Data &
\end{tabular}

*Note: PPF means "Public Provident Fund"; RD means "Recurring Deposit" and FD means "Fixed Deposit."

When asked about preference in trading, $82.6 \%$ of respondents prefer cash trading, whereas $17.4 \%$ prefer future trading.

When respondents have been asked whether they have ever invested in mutual funds, $102(55.4 \%)$ respondents responded in the affirmative, majority (51\%) favoring $10-20 \%$ of the amount reserved for investment in mutual funds, followed by $26.6 \%$ respondents preferring less than $10 \%$ amount reserved for the same. The rest of the 82 respondents have responded that if the right opportunity arises, $20.7 \%$ of them will invest in Mutual funds, $40.2 \%$ of them can invest in mutual funds, $39.1 \%$ will not invest in mutual funds.

However, in the case of options, it is a little bit different scenario. Only 29 (15.8\%) respondents admitted to ever having invested in options. When it comes to preference, the majority $(75.9 \%)$ of respondents, who have ever invested in options have favored both the call 
and put options, whereas $24.1 \%$ of respondents favored only the put option. Out of the remaining respondents (155), who have not used options, only $39(25 \%)$ respondents said that they might invest in options in the future, but the rest of the $116(75 \%)$ respondents rejected the idea to ever invest in options in future.

Swap contracts are a different scenario in itself. No one ever dealt with swap contracts. The majority (73\%) respondents are not even interested in using it, some $(21.7 \%)$ respondents may be interested in the future and a very few (4.3\%) interested, which shows that people here are not much aware of the financial products and are hesitant to use it even after explaining the financial terms making lack of financial literacy quite evident. (Refer to Table A5)

Table A5. Particulars on Mutual Funds, Options, Swap

\begin{tabular}{|c|c|c|c|}
\hline \multicolumn{4}{|c|}{ Mutual Funds } \\
\hline Particulars & & & \\
\hline Dealings with Mutual Funds & Yes(102) & $\mathrm{No}(82)$ & \\
\hline If No, future preference & Yes(17) & $\mathrm{No}(33)$ & May Be(32) \\
\hline \multicolumn{4}{|c|}{ Options } \\
\hline \multicolumn{4}{|l|}{ Particulars } \\
\hline Dealings with Options & Yes(29) & No(155) & \\
\hline If No, future preference & Yes $(0)$ & No(116) & May Be(39) \\
\hline \multicolumn{4}{|c|}{ Swap Contracts } \\
\hline \multicolumn{4}{|l|}{ Particulars } \\
\hline Dealings with Swap & Yes(0) & No(184) & \\
\hline If No, future preference & Yes(8) & $\mathrm{No}(136)$ & May Be(40) \\
\hline
\end{tabular}

One way ANOVA is conducted to see the association between saving and income, and a significant relationship is found at a $5 \%$ level of significance $(F=3.055)$ (Refer to Table A6) but when association between saving and income has been tried to be established by controlling for the effect of variables, namely age, income, and gender through ANCOVA, result is still significant $\left(\mathrm{F}_{3,180}=13.895\right)$ and influencing the factor by $19.1 \%$ at $5 \%$ level of significance. (Refer to Table A7)

Table A6. Association between Annual Saving and Income

Income (in Rs.)

\begin{tabular}{llccccccc} 
S. No & Particulars & $\begin{array}{l}\text { Less } \\
\text { 20000 }\end{array}$ & $\begin{array}{l}\mathbf{2 0 0 0 0 -} \\
\mathbf{5 0 0 0 0}\end{array}$ & $\begin{array}{c}\mathbf{5 0 0 0 0}- \\
\mathbf{8 0 0 0 0}\end{array}$ & $\begin{array}{c}\mathbf{8 0 0 0 0}- \\
\mathbf{1 0 0 0 0 0}\end{array}$ & $\begin{array}{c}\text { More } \\
\mathbf{1 0 0 0 0 0}\end{array}$ & than \\
\hline 1 & Less than100000 & 8 & 0 & 0 & 0 & 0 & 8 \\
2 & $\mathbf{1 0 0 0 0 0 - 3 0 0 0 0 0}$ & 0 & 16 & 8 & 0 & 0 & 24 \\
3 & $\mathbf{3 0 0 0 0 0 - 5 0 0 0 0 0}$ & 4 & 12 & 0 & 8 & 8 & 32 \\
4 & $\mathbf{5 0 0 0 0 0}$ and Above & 0 & 4 & 4 & 0 & 112 & 120 \\
& Total & 12 & 32 & 12 & 8 & 120 & 184 \\
\hline
\end{tabular}

Annual Saving (in Rs.) 
Table A7. Association between Saving and Income with Covariates Age, Gender and Occupation Dependent Variable: Household income saved

\begin{tabular}{lcccccc}
\hline Source & $\begin{array}{c}\text { Type III Sum } \\
\text { of Squares }\end{array}$ & df & Mean Square & F & Sig. & $\begin{array}{c}\text { Partial Eta } \\
\text { Squared }\end{array}$ \\
\hline Corrected Model & $33.058^{\mathrm{a}}$ & 6 & 5.510 & 9.434 & .000 & .242 \\
Intercept & 5.525 & 1 & 5.525 & 9.460 & .002 & .051 \\
Occupation & 7.666 & 1 & 7.666 & 13.126 & .000 & .069 \\
Gender & .350 & 1 & .350 & .599 & .440 & .003 \\
Age & 3.434 & 1 & 3.434 & 5.880 & .016 & .032 \\
Saving & $\mathbf{2 4 . 3 4 4}$ & $\mathbf{3}$ & $\mathbf{8 . 1 1 5}$ & $\mathbf{1 3 . 8 9 5}$ & $\mathbf{. 0 0 0}$ & $\mathbf{. 1 9 1}$ \\
Error & 103.372 & 177 & .584 & & & \\
Total & 1203.000 & 184 & & & & \\
Corrected Total & 136.429 & 183 & & & & \\
\hline
\end{tabular}

a. $\quad$ R Squared $=.242$ (Adjusted R Squared $=.217$ )

Source: SPSS

To see the impact of gender on financial awareness and literacy, one-way MANOVA is conducted. For this impact of gender on priority in instrument decisions, preferred features of instruments, the riskiness of securities, frequency of transactions, dealings in mutual funds and options are observed. A significant impact of gender on priority in instrument decisions, its preferred features, the riskiness of securities and dealings in mutual funds has been found. However, its impact on the frequency of transactions and dealings of options has been found insignificant. (Refer to Table A8). Pillai's Test has been conducted and found significant, which shows that $33 \%$ of the variance of the dependent variable is explained by gender. Box's Test of equality of covariance matrices is found significant at a $5 \%$ level of significance, showing equal covariance among the dependent variables.

Table A8. Impact of Gender on Select Variables

\begin{tabular}{lccccccccc}
\hline & \multicolumn{2}{c}{$\begin{array}{c}\text { Levene's } \\
\text { F(1, }\end{array}$} & \multicolumn{3}{c}{$\begin{array}{c}\text { Annova } \\
\text { F( }\end{array}$} & & \multicolumn{2}{c}{ Male } & \multicolumn{3}{c}{ Female } \\
& $\mathbf{1 8 2})$ & $\mathbf{P}$ & $\mathbf{1 , 1 8 2})$ & $\mathbf{P}$ & $\mathbf{E T A}$ & $\mathbf{M}$ & SD & $\mathbf{M}$ & SD \\
\hline Priority in Instruments & 15.20 & 0 & 3.94 & 0.049 & 0.021 & 9.22 & 2.95 & 8.22 & 3.75 \\
Preferred Features of Instruments & 0.07 & 0.79 & 5.52 & 0.020 & 0.029 & 3.34 & 1.77 & 4.00 & 1.88 \\
Riskiness of Securities & 7.47 & 0.007 & 4.46 & 0.036 & 0.024 & 2.40 & 0.82 & 2.65 & 0.68 \\
Dealing in Mutual Funds & 2.36 & 0.126 & 55.13 & 0.000 & 0.232 & 1.27 & 0.45 & 1.78 & 0.42 \\
Frequency of Transaction & 1.90 & 0.17 & 2.47 & 0.118 & 0.013 & 4.21 & 0.45 & 3.83 & 1.67 \\
Dealing in Option Contracts & 6.82 & 0.01 & 1.56 & 0.214 & 0.008 & 1.82 & 0.39 & 1.89 & 0.32 \\
\hline
\end{tabular}

Source: SPSS

\section{Conclusion and Recommendations}

The standard of living of people has been improving day by day, which in turn makes it essential to save and invest wisely depending on financial literacy, and long and short term goals of the investor (Geetha and Ramesh, 2011). Rather than spending money on high-end items (Mathivannan \& Selvakumar, 2011), people prefer to live comfortably. People are risk-averse and favor safety with tax benefits, liquidity with high returns along with fewer lock-in periods, the findings supported by different studies (Parimalakanthi \& Kumar, 2015; Virani, 2012; Bindu, 2017). People are still cautious and save for the education of their children, housing, and retirement benefits along with other goals in mind like travel.

It is understood through this study that to attain their goals; people should be made more financially literate so that they can match risky with non-risky assets. Financial literacy 
workshops and seminars can be conducted at high school, college, and university levels to make students more financially responsible. This should help investors analyze Investment Avenue from each angle to justify their specific needs. Along with a conservative approach; investors can try to balance it with risky assets to achieve equilibrium in the market while maintaining their nest egg of savings.

By observing people spending and investment behavior, it can be understood, how to encourage people to invest in projects with long gestational periods. Tax incentives can be planned in such a way to encourage people to invest in capital markets in long gestation projects for the development of the country. It will ultimately help in financial inclusion.

However, due to the limitation of funds, sample size and sample frame are limited to 184 and Jammu city, respectively. Due to the constraint of time, the responses of the respondents could not be double-checked. A more significant sample with scope for cross-reference is needed to get a better understanding of the psyche of investors. As it is a small subset, the results cannot be generalized.

Saving and investment are key macro variables with micro-foundations that can play an essential role in the stability and promotion of employment, inflation, economic growth and development of a country, especially a developing one like India.

\section{References}

Achar, A. (2012). Saving and Investment Behaviour of Teachers - An empirical study. International Journal of Physical and Social Sciences, 2(8), 263-286.

Adeyemo, R., \& Bamire, A. S. (2005). Saving and investment patterns of cooperative farmers in Southwestern Nigeria. Journal of social sciences, 11(3), 183-192.

Agrawal, P., Sahoo, P., \& Dash, R. K. (2009). Savings behaviour in South Asia. Journal of Policy Modeling, 31(2), 208224.

Arora, A. (2016). Assessment of Financial Literacy among working Indian Women. Business Analyst, 36(2), $219-237$.

Bahl, S. (2012). Investment Behaviour of Working Women of Punjab. Arth Prabhand: A Journal of Economics and Management, 1(6), 21-35.

Bhushan, P. (2014). Insights into awareness level and Investment Behaviour of salaried individuals towards Financial Products. International Journal of Engineering, Business and Enterprise Applications, 8(1), 53-57.

Bindu, P. K. (2017). Analysis of Investment pattern of college teachers in Kerala. Analysis, 2(2).

Chakraborty, S., \& Digal, S. (2011). A study of saving and investment behaviour of individual households-An empirical evidence from Orissa

Das, S. C., \& Kumar, V. Discretionary Savings and Investment Behaviour of Middle Class Households in India: Empirical Evidence.

Das, S., \& Jain, R. (2014). A study on the influence of demographical variables on the factors of investment-a perspective on the Guwahati region. International journal of research in Humanities, arts and literature, 2, 92-107.

Davar, Y. P., \& Gill, S. (2009). Antecedents of Households' Investment Decision-Making Process: A Study of the Indian Households. South Asian Journal of Management, 16(4).

Dean, A., Durand, M., Fallon, J., \& Hoeller, P. (1989). Saving trends and behaviour in OECD countries.

De Melo, J., \& Tybout, J. (1986). The effects of financial liberalization on savings and investment in Uruguay. Economic Development and Cultural Change, 34(3), 561-587.

Feldstein, M. S., \& Flemming, J. S. (1971). Tax policy, corporate saving and investment behaviour in Britain. The Review of Economic Studies, 38(4), 415-434.

French, K. R., \& Poterba, J. M. (1991). Investor diversification and international equity markets (No. w3609). National Bureau of Economic Research.

Geetha, N., \& Ramesh, M. (2011). A study on people's preferences in Investment Behaviour. International Journal of Engineering and Management Research, 1(6), 285-306.

Gupta, S.P. 2012. Statistical Methods, New Delhi: Sultan Chand \& Sons.

Gupta, N., \& Agarwal, V. (2013). A study of the constituents of domestic savings and investments in urban cities with special focus on Mumbai and Delhi. Indian Journal of Finance, 7(2), 17-26.

Hibbert, A. M., Lawrence, E. R., \& Prakash, A. J. (2012). The role of financial education in the management of retirement savings. Journal of Behavioral Finance, 13(4), 299-307. 
Jain, D., \& Jain, P. (2012). Savings and Investment Pattern of School Teachers-a study with reference to Udaipur District, Rajasthan. International Journal of Research in Commerce, Economics \& Management, 2(6), 119-127.

Kgomo, S. L. (2018). Determinants of investments: a comparative study of RSA Retail Savings Bonds and stokvel(Doctoral dissertation).

Kothari, C. R. (2004). Research methodology: Methods and techniques. New Age International.

Kulkarni, M. S. (2014). A Study Of Investment Behaviour Based On Demographics. Journal of Commerce and Accounting Research, 3(4).

Mathivannan, S., \& Selvakumar, M. (2011). Savings and Investment Pattern of School Teachers-A Study with Reference to Sivakasi Taluk, Tamil Nadu. Indian journal of Finance, 5(4), 12-26.

Ministry of Law and Justice. (2018). The Constitution of India. New Delhi. Government of India.

Nasir, S., Khalid, M., \& Mahmood, A. (2004). Saving-investment behaviour in Pakistan: An empirical investigation [with Comments]. The Pakistan Development Review, 665-682.

Nayaki, K. M. (2014). A Study on Investors Behavior towards the Investment Alternatives with special reference to Coimbatore City.

Olsen, R. A., \& Cox, C. M. (2001). The influence of gender on the perception and response to investment risk: The case of professional investors. The journal of psychology and financial markets, 2(1), 29-36.

Ozcan, K. M., Gunay, A., \& Ertac, S. (2003). Determinants of private savings behaviour in Turkey. Applied Economics, 35(12), 1405-1416.

Pandey, N. S., \& Kathavarayan, P. (2015). Investors' Perception towards Alternativeness and Preferences. SCMS Journal of Indian Management, 12(3), 37.

Parimalakanthi, K., \& Kumar, M. A. (2015). A Study on Investment Preference and behaviour of Individual Investors in Coimbatore City. Bonfring International Journal of Industrial Engineering and Management Science, 5(4), 170.

Perera, A. M. (2016). Gender Attitudes and Investor Behaviour: Evidence from Individual Investors In North Western Province. Economic Research, 4, 1.

Prinsloo, J. W. (2000). The saving behaviour of the South African economy. South African Reserve Bank.

Saikia, S. (2018). Investment Pattern of Youth in India with particular reference to Mumbai.

Samudra, A., \& Burghate, M. A. (2012). A Study on investment behaviour of middle class households in Nagpur. International Journal of Social Sciences and Interdisciplinary Research, 1(5), 43-54.

Senthil, D. (2015). Investor's Behaviour towards Investment Made in Capital Market. Journal of Exclusive Management Science, 4(3), 1-11.

Seward, G. C. (1952). Earned Surplus. Its Meaning and Use in the Model Business Corporation Act. Virginia Law Review, 435-449.

Shukla, A. (2017). Study on Investors' Decision Making Patterns in Kanpur. International Education and Research Journal, 3(6).

Sireesha, P., \& Laxmi, C. (2013). Impact of Demographics on Select Investment Avenues: A Case Study of Twin Cities of Hyderabad and Secunderabad, India.

Sood, D., \& Kaur, N. (2015). A Study of Saving and Investment Pattern of Salaried Class people with special reference to Chandigarh (India). International Journal of Research in Engineering, IT \& Social Sciences, 5(2), 1 15.

Somasundaram, V. K. (1999). A study on the savings and investment pattern of salaried class in Coimbatore district.

Sturm, R. R. (2014). A turning point method for measuring investor sentiment. Journal of Behavioral Finance, 15(1), $30-42$.

Surendar, G., \& Sarma, V. S. (2018). Financial Literacy and Financial Planning Among Teachers of Higher Education-A study of Critical Factors Of Select Variables. International Journal of Pure and Applied Mathematics, 118(18), 1627-1649.

Virani, V. (2013). Saving and Investment Pattern of School Teachers-A Study with Reference to Rajkot City, Gujarat. Abhinav Journal, 2(4), 13-27.

Young, M. S., Geltner, D. M., McIntosh, W., \& Poutasse, D. M. (1995). Defining commercial property income and appreciation returns for comparability to stock market-based measures. Real Estate Finance, 12, 19-31.

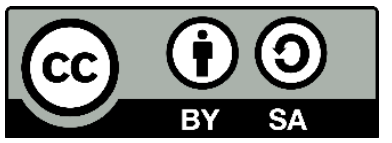

(C) 2019 by the authors. Licensee ACRN Publishing, Austria, Editor in Chief Prof. Dr. Othmar M. Lehner. This article is an open access article distributed under the terms and conditions of the Creative Commons Attribution (CC BY SA) license

(https://creativecommons.org/licenses/by-sa/4.0/) 